\title{
Simulation of Hydrogen Addition and EGR Characteristic on Natural Gas Engine
}

\author{
Jiang Yankun, a , Liu Xin ${ }^{1, b}$,Wu Kaidong ${ }^{1}$ \\ ${ }^{1}$ Huazhong University of Science and Technology,1037 Luoyu Road, Wuhan, P.R. China \\ a jykhust@mail.hust.edu.cn, beslxj@outlook.com
}

\section{Keywords: Natural Gas;Hydrogen;Engine;EGR}

Abstract. Hydrogen addition to natural gas engine will conserve energy and reduce emissions. In this paper, the effects of enriched hydrogen were analyzed and exhaust gas recirculation(EGR) characteristics of hydrogen enriched compressed natural gas(HCNG) engine were simulated. The results show that the ignition time is advanced with more initial hydrogen, which could be attributed to some increasing active group from $\mathrm{H}$-atoms chain-reaction. The results of EGR simulation shown that exhaust gas can reduce the peak temperature and pressure on HCNG engine as well as the NO emission, Finally the Homogeneous Charge Compression Ignition(HCCI) combustion operating area with different EGR ratio was concluded..

\section{Introduction}

Hydrogen is a promising renewable resource, however, there are still some problems if use it as single fuel. Hydrogen addition is an effective way to improve the ignition, combustion and emission characteristics of Natural gas engine and attracted a lot of attention[1,2]. HCCI(Homogeneous Charge Compression Ignition) can also reduce emission and improve fuel efficiency in the same time[3,4]. The combination of these two technologies can effectively reduce the pollution of the engine,but there are few researches about the HCCI combustion on HCNG engine. In this paper, the effect of hydrogen addition to Natural gas and HCCI combustion operating area of HCNG engine were both investigated.

\section{MODEL CONSTRUCTION AND VERIFICATION}

The reaction mechanism used in this paper includes 29 species and 69 elementary reactions, which can be obtained from author. The calculation model contains three parts: inlet, laminar pre-mixed combustion device and outlet. The initial pressure is $0.1 \mathrm{MPa}$ and the environment temperature is $300 \mathrm{~K}$, the composition of natural gas is $96 \% \mathrm{CH}_{4}+3 \% \mathrm{CO}_{2}+1 \% \mathrm{C}_{2} \mathrm{H}_{6}$, equivalent ratio increases from 0.6 to 1.4 by 0.2 while the fraction of hydrogen addition varies among $0 \%, 20 \%$ and $40 \%$.

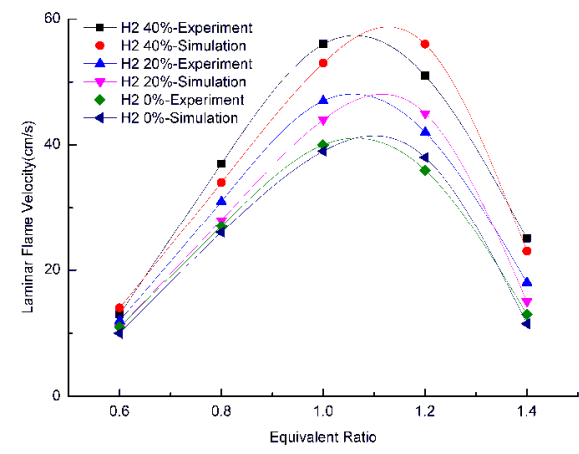

Figure 1 Comparison of experimental and calculated laminar flame velocity

Figure 1 shows a comparison result with experiment data[5]. It seems that the laminar flame velocity increases with the increase of equivalent ratio in each hydrogen fraction and reached the top at 
about $\varphi=1.1$, then slides down sharply in both the experiment and simulation, and the increase of hydrogen fraction will also increase the flame velocity. The trend of curves in simulation results are nearly the same with the experiment.

\section{EFFECT OF HYDROGEN ADDITION ON HCNG ENGINE}

The effect of enriched hydrogen addition to CNG with different hydrogen fractions $(0 \%, 2 \%$ 、 $6 \%, 8 \%$ and $10 \%$ ) are analyzed and compared, the engine specifications are the same as that used in [6].The intake temperature is $442 \mathrm{~K}$, intake pressure is $1 \mathrm{~atm}$, equivalent ratio is 0.3 , engine was operated at constant speed of $1000 \mathrm{r} / \mathrm{min}$ and the wall temperature is $402 \mathrm{~K}$. The composition of natural gas is $99 \% \mathrm{CH}_{4}+1 \% \mathrm{C}_{2} \mathrm{H}_{6}$.

The comparison of temperature and pressure with different hydrogen fraction was shown in Figure 2 respectively. The inflection point of temperature and pressure were both advanced with the increase of hydrogen fraction, the enriched hydrogen will also decrease the peak pressure.

The ignition characteristic of methane is affected by the strong $\mathrm{C}-\mathrm{H}$ chemical bond and the Formaldehyde content at low temperature. The ignition of natural gas is mainly influenced by $\mathrm{OH}+\mathrm{CH}_{2} \mathrm{O}<=>\mathrm{HCO}+\mathrm{H}_{2} \mathrm{O}$. When the temperature is higher than $1400 \mathrm{~K}, \mathrm{CH}_{2} \mathrm{O}$ is generated by the reaction $\mathrm{H}+\mathrm{CH}_{2} \mathrm{O}<=>\mathrm{CH}_{3} \mathrm{O}$ and $\mathrm{CH}_{3} \mathrm{O}+\mathrm{O}_{2}<=>\mathrm{HO}_{2}+\mathrm{CH}_{2} \mathrm{O}$ while in the low temperature period the reaction $\mathrm{CH}_{3}+\mathrm{O}_{2}<=>\mathrm{OH}+\mathrm{CH}_{2} \mathrm{O}$ is more important. The $\mathrm{CH}_{3}$ radical is mainly created by $\mathrm{OH}+\mathrm{CH}_{4}<=>\mathrm{CH}_{3}+\mathrm{H}_{2} \mathrm{O}$, but this reaction became unimportant when temperature is higher than 1900K. $\mathrm{CH}_{3} \mathrm{O}$ is generated mostly from $\mathrm{CH}_{3}$ radical by the reaction $\mathrm{CH}_{3}+\mathrm{O}_{2}<=>\mathrm{O}+\mathrm{CH}_{3} \mathrm{O}$ in low temperature while by $\mathrm{HO}_{2}+\mathrm{CH}_{3}<=>\mathrm{OH}+\mathrm{CH}_{3} \mathrm{O}$ above $1000 \mathrm{~K}$, the second reaction will become more and more important in higher temperature. From the analysis results, it seems that $\mathrm{OH}$ radical and $\mathrm{HO}_{2}$ radical were major active groups for the $\mathrm{C}$ chain reaction.
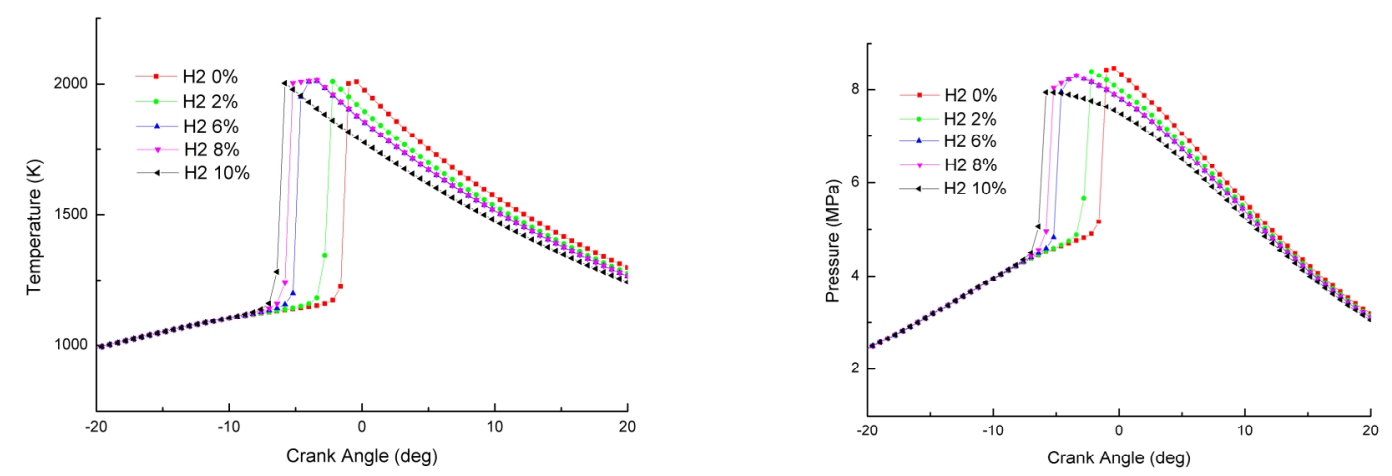

Figure 2 Effect of different hydrogen fraction on cylinder temperature and pressure

$\mathrm{H}+\mathrm{O}_{2}+\mathrm{M}<=>\mathrm{HO}_{2}+\mathrm{M}$ produces $\mathrm{HO}_{2}$ throughout the whole process and $\mathrm{HCO}+\mathrm{O}_{2}<=>\mathrm{HO}_{2}+\mathrm{CO}$ was also important near ignition point. As to $\mathrm{OH}$ radical, the reaction $\mathrm{H}_{2}+\mathrm{O}_{2}<=>2 \mathrm{OH}$ plays important roles at low temperature but net $\mathrm{OH}$ production is few. Reaction $\mathrm{HO}_{2}+\mathrm{CH}_{3}<=>\mathrm{OH}+\mathrm{CH}_{3} \mathrm{O}$ weighs more when the temperature is higher than $1000 \mathrm{~K}$ and $\mathrm{O}+\mathrm{OH}<=>\mathrm{H}+\mathrm{O}_{2}$ and $\mathrm{H}_{2} \mathrm{O}_{2}<=>2 \mathrm{OH}$ are the main source of $\mathrm{OH}$ radical above $1200 \mathrm{~K}$. For pure methane, the generated $\mathrm{OH}$ is so active that it can be reacted quickly with hydrocarbon compounds including $\mathrm{CH}_{2} \mathrm{O}$ and produce much heat, the 
auto-ignition will occur quickly. For the pure $\mathrm{H}_{2}$, the reaction $\mathrm{OH}+\mathrm{H}_{2}<=>\mathrm{H}+\mathrm{H}_{2} \mathrm{O}$ consumes most $\mathrm{OH}$ radical with plenty of $\mathrm{H}_{2}$ above $1200 \mathrm{~K}$ as chain reactions which produce a lot of reactive $\mathrm{H}$ radical, then the global reaction speed is sharply increased and lead to ignition. Moreover, it can be seen from the analysis that $\mathrm{H}_{2} \mathrm{O}_{2}$ are mostly generated by $2 \mathrm{HO}_{2} \longleftrightarrow \Rightarrow \mathrm{O}_{2}+\mathrm{H}_{2} \mathrm{O}_{2}$ above $1200 \mathrm{~K}$ and $\mathrm{OH}+\mathrm{H}_{2} \mathrm{O}_{2}<=>\mathrm{HO}_{2}+\mathrm{H}_{2} \mathrm{O}$ is also important when temperature reached $1700 \mathrm{~K}$. With $\mathrm{H}_{2}$ addition to methane, $\mathrm{H}_{2}+\mathrm{O}_{2}<=>2 \mathrm{OH}$ will produce a little $\mathrm{OH}$ radicals below $700 \mathrm{~K}$ while the reaction $\mathrm{OH}+\mathrm{H}_{2}<=>\mathrm{H}+\mathrm{H}_{2} \mathrm{O}$ plays more important roles in producing heat.

From the above, it can be seen that the enriched hydrogen can not only increase peak temperature but also generate many $\mathrm{H}$ and $\mathrm{OH}$ radicals by chain reactions which will increase $\mathrm{CH}_{3}$ and $\mathrm{CH}_{3} \mathrm{O}$ directly and $\mathrm{CH}_{2} \mathrm{O}$ at second hand, as the results of which, auto-ignition is accelerated and the ignition time is advanced.

\section{EFFECT OF EGR RATIO ON HCNG ENGINE}

Engine will be affected by EGR in many ways: change of initial temperature, dilution to the mixture, high heat capacity and chemical influence.

Hot and cold EGR are simulated respectively and the results were shown in Figure 3. Ignition time will be delayed a lot in cold EGR condition and the main effect of high EGR ratio is decrease the peak temperature.
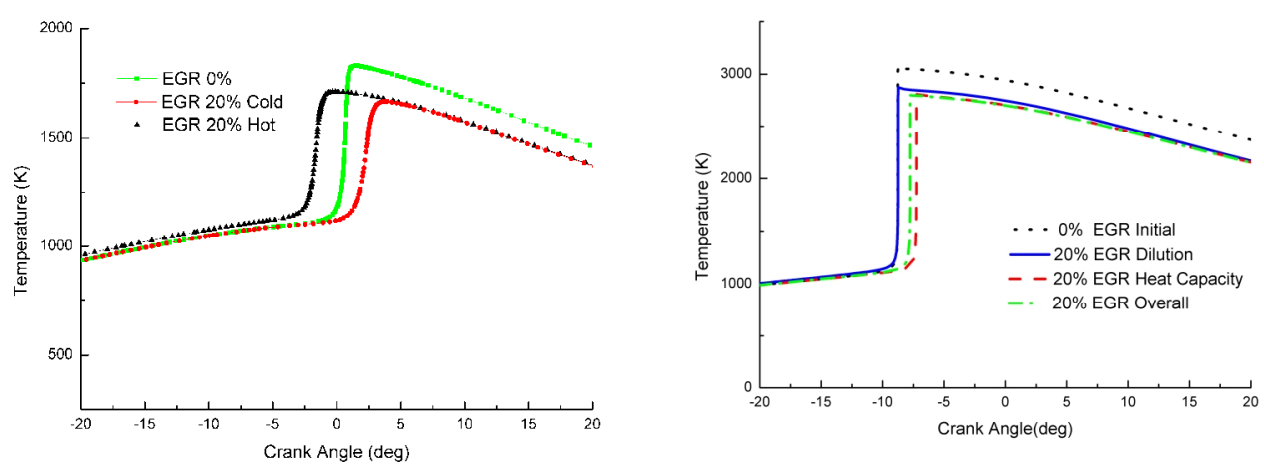

Figure3 Different effects of EGR

The recirculation gas is sets to pure $\mathrm{N}_{2}$ when doing the dilution simulation and $72 \% \mathrm{~N}_{2}+9 \%$ $\mathrm{CO}_{2}+19 \% \mathrm{H}_{2} \mathrm{O}$ in heat capacity study. It seems that dilution effect was not important on ignition but will decrease the peak temperature sharply. The high heat capacity of $\mathrm{H}_{2} \mathrm{O}$ and $\mathrm{CO}_{2}$ will delay ignition and the combustion temperature was also decreased. The curve of overall effects has a little difference with the heat capacity curves in ignition time. This can be attributed to the chemical effect of unburned $\mathrm{HC}$ and other reaction production.

\section{SIMULATION ON OPERATION AREA WITH EGR ON HCNG ENGINE}

HCCI engine is always operated at narrow condition. A method to widen the limit is to control the combustion velocity in high load and increase the intake temperature in high octane fuel and lean burn condition [7]. EGR is respected as an efficient way to expand the operational area. 
Two indexes are defined to judge whether robust and incomplete combustion occur or not. Combustion was considered incomplete if peak temperature is lower than $1400 \mathrm{~K}$ and robust when the mean rate of pressure rise is below $0.8 \mathrm{MPa} /{ }^{\circ} \mathrm{CA}$.

The rate of pressure rise in robust combustion and temperature curve in incomplete combustion with different EGR ratio $(0 \%, 20 \% 、 40 \%$ and $50 \%)$ are calculated. The excess air ratio is 5.5、4.5 、 3 and 2 when the rate of pressure rise is $8 \mathrm{bar} /{ }^{\circ} \mathrm{CA}$ with 0\%、20\%、40\% and 50\% EGR while the incomplete combustion limit is 8.5,6.5, 4.5 and 3.5 .

The HCCI operational area was concluded in Figure 4. There are four parts in the graph and it is divided by incomplete limit (green line), robust limit (red dashed line) and misfire limit (blue dotted line). The encircled area is the general operational area and outside of the three lines is the specific abnormal combustion area. The operational area will become narrower and move to the part of low excess air ratio with the increasing EGR ratio.

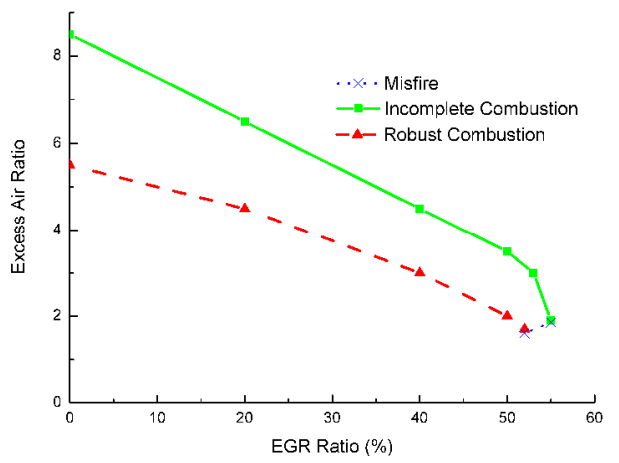

Figure 4 HCCI operational area on HCNG engine

\section{CONCLUSION}

1) The ignition time is increased with higher hydrogen fraction. The main reason is that the enriched $\mathrm{H}_{2}$ will produce more heat and $\mathrm{H}$ radicals to accelerate the generation of $\mathrm{OH} \backslash \mathrm{HO}_{2} \backslash \mathrm{CH}_{3} \backslash \mathrm{CH}_{3} \mathrm{O}$, which provide perfect production environment for the $\mathrm{CH}_{2} \mathrm{O}$ and lead to the advanced auto-ignition.

2) With hot exhaust gas recirculation, the cylinder temperature and pressure will be lowered and the ignition time is advanced, While the ignition time delayed if the intake mixture is cooled. The phenomenon of the lowered peak temperature is mainly caused by dilution effect and the improved ignition performance could due to high heat capacity. The chemical effect will also advance the ignition.

3) The HCCI operational area in HCNG engine was concluded, the area will tend to low excess air ratio part and become narrower with higher EGR ratio.

\section{References}

[1] Gaurav Verma, Rajesh Kumar Prasad,et al. Fuel, Vol.178(2016), p.209-217.

[2] F. Amrouche, P.A. Erickson,et al. Energy Conversion and Management, Vol.123(2016), p.174-184.

[3] M.M. Hasan, M.M. Rahman. Renewable and Sustainable Energy Reviews, Vol.57(2016), pp.282-291. 
[4] Dallin S. Bullock, Jason S. Olfert. Journal of Aerosol Science, Vol.75(2014), p. 1-8.

[5] Wang J H, Huang Z H, et al. China National Symposium on Combustion.Oct,2008.

[6] Fiveland S B, Agama R, et al.Society of Automotive Engineer,Paper 2001-01-3609.

[7] Wagner R M, Edwards K D, Daw C S, et al. Society of Automotive Engineer, Paper 2006-01-0418 